\title{
Can athletes with type 1 diabetes use supplementation?
}

\section{Czy sportowcy z cukrzycą typu 1 mogą stosować odżywki?}

\author{
${ }^{1}$ Agnieszka Lejk, ${ }^{1}$ Małgorzata Myśliwiec, ${ }^{2}$ Artur Myśliwiec \\ ${ }^{1}$ Department of Paediatrics, Diabetology and Endocrinology, Medical University of Gdansk, Poland \\ ${ }^{2}$ Department of Sports Physiology, University of Physical Education and Sport in Gdansk, Poland
}

\begin{abstract}
From year to year, we observe constantly growing revenue from the sale of supplements and functional food for athletes. The increased interest in their use raises many questions concerning the choice of products, portions, in addition in the case of athletes with type 1 diabetes - how they affect the level of glycaemia. In the group of people under 18 with diagnosed type 1 diabetes, the properly selected supplementation, which will not cause undesirable effects, is even more important. This publication aims to summarize the current reports on nutrients that come from: the present scientific knowledge, information on the labels, and information available on the websites of the most popular companies producing nutrients on the Polish market.
\end{abstract}

\section{Key words:}

supplementation, diabetes type 1, athletes, protein.

\section{Streszczenie}

Z roku na rok obserwuje się stale rosnące przychody ze sprzedaży suplementów i żywności funkcjonalnej dla sportowców. Rosnące zainteresowanie ich zastosowaniem rodzi wiele pytań dotyczących wyboru produktów, porcji, a także w przypadku sportowców z cukrzycą typu 1 - w jaki sposób wpływają one na poziom glikemii. W grupie osób poniżej 18. roku życia z rozpoznaną cukrzycą typu 1 odpowiednio dobrana suplementacja, która nie spowoduje niepożądanych skutków, jest jeszcze ważniejsza. Niniejsza publikacja ma na celu podsumowanie bieżących raportów na temat odżywek, które pochodzą z: aktualnej wiedzy naukowej, informacji na etykietach oraz informacji dostępnych na stronach internetowych najpopularniejszych firm produkujących odżywki na polskim rynku.

\section{Słowa kluczowe:}

suplementy diety, cukrzyca typu 1, sportowcy, białko. 


\section{Introduction}

Since 2011, dynamic development of sports supplements has been observed in Poland. According to the research by the Supreme Audit Office, it is forecasted that in 2020 Poles will spend over 5 billion on their purchase [1]. Such rapid increase in the interest in the supplement consumption raises numerous questions concerning the choice of products, used portions, and in the case of athletes with type 1 diabetes; how they affect the level of glycaemia [2]. Increasingly, they are used by the group of boys under 18, whose main goal is to build muscle mass in the shortest possible time [3].

The supplements industry in Poland has numerous drawbacks, which include: lack of proper legal regulations, unqualified personnel engaged in the distribution and inappropriate composition [4]. There are many classifications of nutrients that are used in the diet of athletes. One of them was presented by Zając et al., who distinguished dietary supplement products and the other supplements. According to the accepted definition "dietary supplements are a concentrated source of nutrients or other substances with nutritional or physiological effects".

Additionally, it was emphasized that their composition is so chosen that it supplements the significant deficiencies of minerals and vitamins that occur in the group of athletes [5].

On the basis of Food safety and nutrition Act of 25 August 2006, Journal of Laws 2006 No 171, sports supplements are 'put on the market for the purpose of satisfying special nutritional needs, in particular athletes' [6].

Tomaszewski et al. presented it differently in the publication in which the nutrients were divided due to the presence of a macronutrients in them: protein, protein-carbohydrate and carbohydrate [7].

In the case of regular training, it is important to choose the right nutrition and adjust its portions to the frequency and type of exercise, taking into account a properly arranged nutritional plan [8].

In the group of people under 18 years of age with diagnosed type 1 diabetes, the properly selected supplementation, which will not cause undesirable effects, becomes even more important [9]. This article aims to summarize the reports on nutrients, which are based on the current scientific knowledge and compare it with the facts on the nutrition labels and information on the websites of the most popular companies producing nutrients for the Polish market.

\section{Protein supplements - characteristics}

The most popular and frequently used are the protein supplements. The chief purpose of using protein powder by amateur and professional athletes is to restore damaged muscle fibers because of intense physical effort [10]. The demand for protein in children depends on the type of physical activity.

If the physical activity is low or moderate, the daily protein intake should be approx. 1-1.5 g per $\mathrm{kg}$ of body weight per day [11].
In order to cover the protein demand during the period of intense workouts, athletes often use supplementation.

Protein supplements can be divided due to the type of protein from which they were produced:

- dairy proteins (whey, casease),

- egg white,

- meat protein (beef),

- vegetable protein (soy) [12].

However, athletes often choose protein supplements, which are rich in branched-chain amino acids (BCAA), due to their functions.

However, in the selection of protein supplements, athletes are most often guided by the content of branched chain amino acids (BCAAs) due to their functions. The most common positive effects on the human body include: muscle growth acceleration, muscle endurance increment, reduction of adipose tissue [13].

However, it was differently presented in the Wolf publication, which focused on the analysis of research related to the BCAA impact on the stimulation of muscle protein synthesis and the anabolic response. Conclusions from his work did not confirm the beneficial effect of supplementation with branched chain amino acids [14]

Secondly, when choosing protein nutrients, the time of protein absorption by human body is immensely important.

On this basis, we can be divided in the following way:

- fast absorbing proteins (whey in the form of isolate and hydrolizate, soy and beef);

- intermediate absorbtion proteins (whey protein concentrates);

- slowly absorbed proteins (milk protein, egg white) [15].

Tang et al. and West et al. come to a similar conclusions that clearly indicate that whey proteins have the advantage in stimulating muscle protein synthesis by comparing them with other sources, including those considered as fast-absorbing soy and casein $[16,17]$.

Not only the time of protein absorbtion is important, but their appropriate source and degree of processing. The most widely studied proteins include whey proteins in the form of hydrolysates and isolates due to their BCAA and leucine content, which have the greatest effect on the amino acid concentration in the body [18].

\section{Selection of protein supplements}

Several companies on the Polish market are the leaders in the production and distribution of protein supplements. Based on information obtained from websites and directly from the label on the packaging of the product we can compare various protein supplements in terms of their carbohydrate, protein, fat, vitamins, minerals, colouring, flavours and preservatives [19].

One of the analysed examples is a conditioner made on the basis of whey protein concentrate.

In Table I is shown composition of analysed product [20]. 
Table I. Composition of the selected protein concentrate

\begin{tabular}{lll}
\hline Nutritional value & $100 \mathrm{~g}$ & $30 \mathrm{~g}$ (portion) \\
\hline Energy value & $390 \mathrm{kcal}$ & $118 \mathrm{kcal}$ \\
\hline Fat & $7.6 \mathrm{~g}$ & $2.3 \mathrm{~g}$ \\
\hline Including saturated fatty acids & $5.3 \mathrm{~g}$ & $1.6 \mathrm{~g}$ \\
\hline Carbohydrates & $4.3 \mathrm{~g}$ & $1.3 \mathrm{~g}$ \\
\hline Including sugars & $4.3 \mathrm{~g}$ & $1.3 \mathrm{~g}$ \\
\hline Protein & $76 \mathrm{~g}$ & $23 \mathrm{~g}$ \\
\hline Salt & $1.5 \mathrm{~g}$ & $0.5 \mathrm{~g}$ \\
\hline
\end{tabular}

On this basis, it can be noticed that the important information for children with type 1 diabetes is the fact that it contains not only protein, but also simple carbohydrates and saturated fatty acids.

The second particularly important information is the portion of protein in the volume declared by the producer. Based on the available publications on this topic, it is valid in a single portion of protein supplement [21].

The next analysed product is a nutrient produced on the basis of a protein derived from milk (Table II).

Firstly, it should be noted that supplement is not intended for children with lactose intolerance and should not be used by them [22]. On the basis of the information contained on the packaging, it can be seen that in the portion recommended by the producer there is $1 \mathrm{CE}$ (carbohydrate exchange), appropriate amount of protein and significant amount of saturated fatty acids.

Based on the information on the packaging, it can be seen that the portion recommended by the manufacturer contains $1 \mathrm{CE}$ (carbohydrate exchange), an adequate amount of protein and a considerable amount of saturated fatty acids.

However, attention should also be paid to the salt content. Currently, the Institute of Food and Nutrition in Warsaw clearly emphasizes that children aged 2-15 should not consume more than $3.5 \mathrm{~g}$ of salt per day and when they are over 16 years old not more than $5 \mathrm{~g}$ of salt per day [23]. The average salt content per portion declared by the manufacturer is $0.28-0.5 \mathrm{~g}$, which means it can be relatively high adding consumption of salt with food.

During further analysis of the product's composition, it can be seen that sweeteners, dyes and aromas are often added to protein supplements. The sweet taste is achieved by adding artificial sweeteners such as: acesulfame - K, aspartame, sucralose. Numerous publications highlight their negative impact on the human body through triggering neurological problems: migraine headaches, hyperactivity [24], and carcinogenic effects [25]. A suitable colour of the protein supplements is
Table II. Composition of protein supplement based on cow's milk

\begin{tabular}{llll}
\hline Composition & $\begin{array}{l}\text { Per } \\
\text { serving } \\
(35 \mathrm{~g})\end{array}$ & $\begin{array}{l}\text { For } \\
3 \text { servings } \\
(105 \mathrm{~g})\end{array}$ & For $100 \mathrm{~g}$ \\
\hline Energy value & $145 \mathrm{kcal}$ & $435 \mathrm{kcal}$ & $413 \mathrm{kcal}$ \\
\hline $\begin{array}{l}\text { Fat including } \\
\text { saturated fatty acids }\end{array}$ & $3.1 \mathrm{~g}$ & $9.2 \mathrm{~g}$ & $8.8 \mathrm{~g}$ \\
\hline Carbohydrates & $11 \mathrm{~g}$ & $33 \mathrm{~g}$ & $32 \mathrm{~g}$ \\
\hline Including sugars & $1.7 \mathrm{~g}$ & $5.1 \mathrm{~g}$ & $4.9 \mathrm{~g}$ \\
\hline Roughage & $0 \mathrm{~g}$ & $0 \mathrm{~g}$ & $0 \mathrm{~g}$ \\
\hline Protein & $23 \mathrm{~g}$ & $68 \mathrm{~g}$ & $65 \mathrm{~g}$ \\
\hline Salt & $0.28 \mathrm{~g}$ & $0.84 \mathrm{~g}$ & $0.80 \mathrm{~g}$ \\
\hline
\end{tabular}

Table III. Composition of a pineapple - coconut flavoured protein shake

\section{Pineapple - coconut flavoured protein shake:}

water, whey protein concentrate, pineapple juice: $16 \%$, apple juice: $3 \%$, coconut water: $0.5 \%$, stabilisers (pectin, guar gum), sweeteners (sucralose, acesulfame - K), colouring concentrates (safflower, lemon), acidity regulator (lactic acid, citric acid, ascorbic acid), flavouring

achieved most frequently through the addition of quinoline yellow. Its biggest flaw is the release of considerable amounts of histamine, which triggers an allergic reaction. The first symptom includes asthma, urticaria, red skin and rash. If a child shares such symptoms, it can even lead to an anaphylactic shock. Quinoline yellow has been classified as a factor predisposing to the development of cancer [26].

Ready-made products, available on the market in the form of protein shakes, cannot be omitted too. After an analysis of a chosen product and familiarising with the composition shown on the package, the conclusions are as follows: one portion contains only $1 \mathrm{CE}$, the volume of protein amounts to $26 \mathrm{~g}$, meaning that it falls within the norm of adequate protein contained in the portion and - which is very important - it contains a considerable number of substances presented in Table III [27].

After familiarisation with the way that the supplement market operates, many flaws can be observed. Often, the places in which you can buy a protein supplement do not have their personnel trained on how to properly advise their customers 
which protein supplement to pick and how to dose it. This is especially important within the group of children that are interested in supplementation, as during the periods of heightened body development the supplementation does not satisfy all the needs; a proper physical and cognitive development requires a suitable and properly selected nutrition [28].

A very frequent mistake made when using protein supplementation is not properly accounting for the amount of physical exercise when measuring the dose. In the process of glucogenesis, the excessive supply of protein is converted into glucose, then triglycerides, in the liver. This conversion leads to an accumulation of fat tissue instead of muscle mass [29].

Other consequences of excess supplementation of protein include:

- An increase of urination, which - coupled with physical exercise - might lead to dehydration.

- An increase of excretion of calcium with urine, which can lead to bone decalcification.

- An increased risk of kidney stones and gout

- An excessive accumulation of gas in the intestines [30].

\section{Carbohydrate supplements - characteristics}

Another type of supplements available on the Polish market is carbohydrate supplements. According to the ISPAD (International Society for Pediatric and Adolescent Diabetes) guidelines, the carbohydrate demand in the group of children with type 1 diabetes that engage in an intensive physical exercise is $1-1.5 \mathrm{~g} / \mathrm{kg}$ of body weight per day [31].

Table IV. Composition of a carbohydrate supplement

\begin{tabular}{lll}
\hline Composition & $\begin{array}{l}\text { Per portion } \\
(100 \mathrm{~g})\end{array}$ & $\begin{array}{l}\text { Per } 2 \text { portions } \\
(200 \mathrm{~g})\end{array}$ \\
\hline Caloric value & $376 \mathrm{kcal}$ & $752 \mathrm{kcal}$ \\
\hline Fat, & $1.8 \mathrm{~g}$ & $3.6 \mathrm{~g}$ \\
\hline $\begin{array}{lll}\text { including saturated fatty } \\
\text { acids }\end{array}$ & $1.0 \mathrm{~g}$ & $2.0 \mathrm{~g}$ \\
\hline Carbohydrates, & $75 \mathrm{~g}$ & $150 \mathrm{~g}$ \\
\hline including sugars & $32 \mathrm{~g}$ & $64 \mathrm{~g}$ \\
\hline Dietary fibre & $0 \mathrm{~g}$ & $0 \mathrm{~g}$ \\
\hline Proteins & $15 \mathrm{~g}$ & $30 \mathrm{~g}$ \\
\hline Salt & $0.43 \mathrm{~g}$ & $0.86 \mathrm{~g}$ \\
\hline Creatine monohydrate & $1500 \mathrm{mg}$ & $3000 \mathrm{mg}$ \\
\hline Taurine & $500 \mathrm{mg}$ & $1000 \mathrm{mg}$ \\
\hline
\end{tabular}

The main reason for using such supplements is to supply the body with energy, which has been lost during physical exercise.

It is recommended to take them directly after:

- strength training,

- endurance training: cycling, swimming and triathlon

- interval training: crossfit [32].

A number of publications highlight the benefits of carbohydrate supplementation. One of them is a review paper Stellingwerff and Cox, which sums up 61 scientific reports. Based on them, it has been concluded that $82 \%$ of studies indicate a beneficial effect of carbohydrate supplements, while only $18 \%$ cites the placebo effect [33].

According to our current knowledge on carbohydrates, the speed of carbohydrate oxidation in the muscle tissue, it is advised to consume the supplements containing a combination of simple carbohydrates [34]. Both Currell and Jeukendrup. Have concluded that the combination of glucose, saccharose and maltodextrin increases the oxidation of carbohydrates when compared to individual consumption [35].

\section{Selection of carbohydrate supplements}

Across the range of available carbohydrate supplements available in distribution points, there are supplements containing the abovementioned combinations of carbohydrates. However, it is important to pay attention to how such products can affect children with type 1 diabetes. The table below presents the composition of a selected carbohydrate supplement (Table IV)

The most important information for children with type 1 diabetes is carbohydrate content. It is especially important to pay attention to carbohydrate exchange, which is 7.5 per 100 $\mathrm{g}$ of the product. It is worth noting that half of the carbohydrates contained in the analysed supplement are simple sugars of high Gl (glycemic index). Choosing the abovementioned product could be questionable with children that have type 1 diabetes primarily because of a very high carbohydrate content, which can negatively impact glycemia [36]. Even in carbohydrate supplements the amount of salt is high. Compared to protein supplements the amount of salt per portion is more or less similar.

\section{Carbohydrate - protein supplements - characteristics}

Supplements that are very often offered in distribution points are those that contain both carbohydrates and protein. On the Polish market there are two types of such supplements, with differing content of these macronutrients:

- "gainer" supplements (carbohydrates - 60-80\%, protein 20-40\%)

- "bulk" supplements (carbohydrates - 50\%, protein -50\%) [37].

They are meant to replenish the energy reserves exhausted during physical exercise. They are used mainly by people that 
undergo intensive speed - strength training and those aiming to improve the way they look [38].

A number of publications discussing carbohydrate - protein supplements indicate that their use is questionable due to meagre post-training effects. McLellan TM and associates note that the carbohydrates contained in the supplements are beneficial for energy supply, but protein intake does not contribute towards faster regeneration and an increase in efficiency in sportsmen [39].

\section{Creatine - legal doping}

As of today, most of the scientific reports focus on creatine as one of the best supplements for sportsmen. This compound contains such amino acids as: arginine, glycine and methionine, which are present, above all, in muscle tissue. Their proper supply increases ATP in muscles, thus improving the posttraining regeneration rate and boosting the increase of muscle mass [40].

Farshidfar et al. have analysed the impact of creatine supplementation on its metabolism in the body. They suggest that creatine influences the protein synthesis in the human body across a variety of processes, thus leading to the aforementioned results during the supplementation [41].

One of the groups that are interested in that supplement is teenage boys that aim at improving their physical appearance. A quick increase the muscle mass becomes so desired that they disregard the negative consequences of its overuse. A lot of scientific research has been concentrated on the analysis of its inadequate consumption and its effects on the human body. Hall and Trojian have been paid attention to the safety of creatine supplementation. Consuming it in doses larger than recommended for periods exceeding several months leads to kidney and liver complications [42].

On the other hand, Francaux and Poortmans suggest that the main flaw of the creatine that is available on the market is the addition of a variety of other substances present in other supplements [43].

\section{General characteristics of supplements}

According to the definition contained in the Act of $25 \mathrm{Au}$ gust 2006 on food and nutrition safety (Journal of Laws No. 171, item 1225, Article 3, paragraph 39), "Food supplement is a foodstuff which purpose is to supply a normal diet with concentrated source of vitamins or minerals or other substances with a nutritional or other physiological effect" [44]. In Poland, dietary supplements that have been marketed do not need to be tested, which means that the declared amount of macronu- trients and microelements may differ from what is included on the packaging. Due to the lack of confidence in dietary supplements, their everyday use should be consulted with a doctor or dietitian. It should also be noted that according to the Pharmaceutical Law, a medicament is the only tested product in terms of particular nutrients [45].

On the other hand, it should be emphasized that a properly balanced diet should cover the demand for all macronutrients and microelements so the supplementation is not necessary. Unfortunately, children's current eating habits often differ from the principles of proper nutrition. There is a significant shortage of vegetables, fruits, dietary fiber, omega 3 fatty acids and an excess of saturated fat, simple sugars. In most cases, instead of making changes to current eating habits, parents reach for supplements, which is the easiest way. Changing eating habits and consulting with a nutritionist will be a better choice for them [46].

\section{Summary}

After familiarising with current scientific research, publications of review papers and information available online, a few important conclusions regarding the use of supplementations can be reached.

The first conclusion relates to the proper choice of conditioner and the quantity of consumed supplements in the context of physical activity. In case of persons under 18 years of age that partake in intense training, it is worth consulting with people that have received a proper education in that direction, for example, sport dieticians. Consuming a protein supplement along with proper dietary plan can lead to achieving the desired effect without suffering any health consequences.

If sportsmen suffer from chronic diseases, such as the abovementioned type 1 diabetes, it is important to consider the type of supplement used. Carbohydrate supplements that contain $50 \%$ of simple sugars with a high Gl can negatively impact glycaemia when consumed in excessive quantities.

When making a choice, it is also important to focus on a thorough analysis of the contents of a given product. Some supplements contain lactose, which can cause an allergic reaction.

In order to achieve a long expiration date, as well as a proper taste and colour of the product, the producers add a number of additive substances, such as preservatives, colouring and flavouring. A number of publications discuss the negative impact of food additives on the human body.

To sum up, supplement which contains more than $20 \mathrm{~g}$ of protein per serving and a minimal amount of artificial additives, consumed in a proper quantity, along with a diet and exercise plan can have a positive impact on the body through a gradual increase of muscle mass, better training result or increased regeneration after the training. 


\section{References}

1. Supreme Chamber of Control. https://www.nik.gov.pl/en/ (as at 12.02.2019).

2. Kerksick CM, Wilborn CD, Roberts MD, et al. ISSN Exercise \& Sports Nutrition Review Update: Research \& Recommendations. J Int Soc Sports Nutr 2018; 15: 38. doi: 10.1186/s12970-018-0242-y

3. Parnell JA, Wiens KP, Erdman KA, et al. Dietary Intakes and Supplement Use in Pre-Adolescent and Adolescent Canadian Athletes. Nutrients 2016; 8: 526. doi: 10.3390/nu8090526

4. Grzebisz N. Functional foods in the diet of athletes. KNUV 2017; 2: $237-246$

5. Zając A, Poprzęcki S, Czuba M, Szukała D. Dietary and supplementary support of the training process. AWF, Katowice 2010.

6. Act of 25 August 2006 on food and nutrition safety: Journal of Laws 2006 No. 171 item 1225

7. Kurylas A, Kwiatkowska-Pamuła A, Gniza D. Dietary supplement intake by recreationally trained men and motives behind these procedures. Journal of Education, Health and Sport 2017; 7: 84-97. doi: http://dx.doi.org/10.5281/zenodo.231322

8. 8. Delavier F, Gundill M. Food supplements for athletes. Publishing House AHA; 2010.

9. Jarosz M, Ciok J, Respondek W. Dietary supplements and health. Medical Publishing House PZWL, Warszawa 2013.

10. Jäger R, Kerksick CM, Campbell $\mathrm{BI}$, et al. International society of sports nutrition position stand: protein and exercise. J Int Soc Sports Nutr 2017; 14: 20. doi: 10.1186/s12970-017-0177-8

11. Gracia-Marco L, Bel-Serrat S, Cuenca-Garcia M, et al. Amino acids intake and physical fitness among adolescents. Amino Acids 2017; 49: 1041-1052. doi: 10.1007/s00726-017-2393-6

12. Cintineo PH, Arent AM, Antonio J, et al. Effects of Protein Supplementation on Performance and Recovery in Resistance and Endurance Training. Front Nutr 2018; 5: 83. doi: 10.3389/fnut.2018.00083

13. Massimo N, Segreto V, Barbero M, et al. Essential Amino Acids (EAA) Mixture Supplementation: Effects of an Acute Administration Protocol on Myoelectric Manifestations of Fatigue in the Biceps Brachii After Resistance Exercise. Front Physiol 2018; 9: 1140. doi: 10.3389/fphys.2018.01140

14. Wolfe RR. Branched-chain amino acids and muscle protein synthesis in humans: myth or reality? J Int Soc Sports Nutr 2017; 14: 30. doi: 10.1186/s12970-017-0184-9

15. Jager R, Kerksick MCh, Cambell IB. International society of sports nutrition position stand: protein and exercise. J Int Soc Sports Nutr 2017; 14: 20. doi: 10.1186/s12970-017-0177-8

16. Tang JE, Moore DR, Kujbida GW, et al. Ingestion of whey hydrolysate, casein, or soy protein isolate: effects on mixed muscle protein synthesis at rest and following resistance exercise in young men. J App Physiol 2009; 107: 987-992. doi: 10.1152/japplphysiol.00076.2009

17. West DW, Burd NA, Coffey VG, et al. Rapid aminoacidemia enhances myofibrillar protein synthesis and anabolic intramuscular signaling responses after resistance exercise. Am J Clin Nutr 2011; 94: 795-803. doi: 10.3945/ajcn.111.013722

18. Burd NA, Yang Y, Moore DR, et al. Greater stimulation of myofibrillar protein synthesis with ingestion of whey protein isolate $\mathrm{V}$. Micellar casein at rest and after resistance exercise in elderly men. Br J Nutr 2012; 108: 958-962. doi: 10.1017/S0007114511006271
19. Delavier F, Gundill M. Food supplements for athletes. Publishing House AHA; 2010.

20. Fitness Authority. https://www.fanutrition.pl (as at 15.02.2019).

21. Olimp. https://www.olimp.pl (as at 15.02.2019).

22. Heine R.G, Alrefaee F, Bachina P, et al. Lactose intolerance and gastrointestinal cow's milk allergy in infants and children - common misconceptions revisited. World Allergy Organ J 2017; 10: 41. doi: 10.1186/s40413-017-0173-0

23. Jarosz M. Norms of human nutrition for the Polish population. Instytut Żywności i Żywienia; Warszawa 2017.

24. Erbaş O, Erdogan MA, Khalilnezhad A, et al. Evaluation of longterm effects of artificial sweeteners on rat brain: a biochemical, behavioral, and histological study. J Biochem Mol Toxicol 2018; 32: e22053. doi: 10.1002/jbt.22053

25. Sharma A, Amarnath S, Thulasimani M, et al. Artificial sweeteners as a sugar substitute: Are they really safe? Indian J Pharmacol 2016; 48: 237-240. doi: 10.4103/0253-7613.182888

26. Eugene Arnold L, Lofthouse N, Hurt E. Artificial Food Colors and Attention-Deficit/Hyperactivity Symptoms: Conclusions to Dye for. Neurotherapeutics 2012; 9: 599-609. doi: 10.1007/s13311-0120133-x

27. Scitec Nutrition. http://www. daily-protein.de/index.php/scitec-nutrition-protein-smoothie (as at 15.02.2019).

28. Bornstein MH, Rebello Britto P, Nonoyama-Tarumi Y, et al. Child Development in Developing Countries: Introduction and Methods. Child Dev 2012; 83: 16-31. doi: 10.1111/j.1467-8624.2011.01671.x

29. Kincaid MR, Granner DK, Rodwell VW. Harper Biochemistry. Medical Publishing House PZWL, Warszawa 2012.

30. Samal JRK, Samal IR. Protein Supplements: Pros and Cons. J Diet Suppl 2018; 15: 365-371.

31. Robertson K, Riddell MC, Guinhouya BC, et al. Exercise in children and adolescents with diabetes. Pediatric Diabetes 2014; 15 (Suppl. 20): 203-223. doi: 10.1111/pedi.12176

32. Hun-Young P, Kim J, Park M, et al. The effect of additional carbohydrate supplements for 7 days after pro-longed interval exercise on exercise performance and energy metabolism during submaximal exer-cise in team-sports athletes. J Exerc Nutrition Biochem 2018; 22: 29-34.

33. Stellingwerff T, Cox GR. Systematic review: Carbohydrate supplementation on exercise performance or capacity of varying durations. Appl Physiol Nutr Metab 2014; 39: 998-1011. doi: 10.1139/ apnm-2014-0027

34. Williams C, Rollo I. Carbohydrate Nutrition and Team Sport Performance. Sports Med 2015; 45 (Suppl 1): 13-22. doi: 10.1007/ s40279-015-0399-3

35. Currell K, Jeukendrup AE. Validity, reliability and sensitivity of measures of sporting performance. Sports Med 2008; 38: 297-316. doi: 10.2165/00007256-200838040-00003

36. Olimp. http:// www.olimp.pl (as at 18.02.2019).

37. Andersen G, Ørngreen MC, Preisler N, et al. Protein-carbohydrate supplements improve muscle protein balance in muscular dystrophy patients after endurance exercise: a placebo-controlled crossover study. Am J Physiol Regul Integr Comp Physiol 2015; 308: R123-R130. doi: 10.1152/ajpregu.00321.2014

38. Pasiakos S, Lieberman HR, McLellan TM. The Effects of Protein Supplements on Muscle Mass, Strength, and Aerobic and Anaerobic 
Power in Healthy Adults: A Systematic Review. Sports Med 2014; 45: 111-131. doi: 10.1007/s40279-014-0242-2

39. McLellan TM, Pasiakos SM, Lieberman HR. Effects of protein in combination with carbohydrate supplements on acute or repeat endurance exercise performance: a systematic review. Sports Med 2014; 44: 535-550. doi: 10.1007/s40279-013-0137-7

40. Cooper R, Naclerio F, Allgrove J, et al. Creatine supplementation with specific view to exercise/sports performance: an update. J Int Soc Sports Nutr 2012; 9: 33. doi: 10.1186/1550-2783-9-33

41. Farshidfar F, Pinder MA, Myrie SB. Creatine Supplementation and Skeletal Muscle Metabolism for Building Muscle Mass - Review of the Potential Mechanisms of Action. Curr Protein Pept Sci 2017; 18 : 1273-1287. doi: 10.2174/1389203718666170606105108
42. Hall M, Trojian TH. Creatine supplementation. Curr Sports Med Rep 2013; 12: 240-244. doi: 10.1249/JSR.0b013e31829cdff2

43. Francaux M, Poortmans JR. Side effects of creatine supplementation in athletes. Int J Sports Physiol Perform 2006; 1: 311-323. doi: 10.1123/ijspp.1.4.311

44. Act of 25 August 2006 on food and nutrition safety. Journal of Laws No. 171, item 1225, Article 3, paragraph 39.

45. Dwyer TJ, Coates PM, Smith JM. Dietary Supplements: Regulatory Challenges and Research Resources. Nutrients 2018; 10: 41. doi: 10.3390/nu10010041

46. Weker $\mathrm{H}$, Barańska M, Riahi A, et al. Nutrition of infants and young children in Poland - Pitnuts. Dev Period Med 2017; 21: 13-28. 